\title{
PERANAN KEPEMIMPINAN PEREMPUAN DALAM MEMODERASI PENGARUH CORPORATE SOCIAL RESPONSIBILITY DISCLOSURE DAN SCORING GOOD CORPORATE GOVERNANCE TERHADAP NILAI PERUSAHAAN
}

\author{
Ferdiya Devika, Indah Yuliana \\ Jurusan Manajemen, Fakultas Ekonomi, UIN Maulana Malik Ibrahim Malang, Indonesia \\ Email: ferdiyadevika26@gmail.com
}

\begin{abstract}
This study aimed to investigate the role of women in the leadership of the board of directors does play a role moderating influence strengthens or weakens the disclosure of Corporate Social Responsibility and Good Corporate Governance Scoring Against Corporate Values. Our study provides new insights into the effect of disclosure of Corporate Social Responsibility and Good Corporate Governance Scoring Against Corporate Values. Women's leadership within the board of directors is a form of board diversity of companies. Diversity is one of the board members have a firm sign of good governance as it reflects the absence of discrimination within the company means that anyone can be a board of directors of the company so as to encourage men and women to compete enhance the reputation and value of the company. The study consisted of 18 sample companies sub-sector bank by using purposive sampling during the period from 2015 to 2018 while the analytical methods we use are Moderate Regression Analysis. The results of our study indicate that partial disclosure of Corporate Social Responsibility has no influence on the value of the company, while Scoring GCG has a significant negative effect on the value of the Company. Besides the leadership of women in the board of directors acts as a pure moderation to strengthen the influence of Corporate Social Responsibility disclosure on corporate value and strengthen the influence of Good Corporate Governance Scoring against the value of the Company. Our findings have important implications for the company.
\end{abstract}

Keywords:Corporate Social Responsibility disclosure, Scoring Good Corporate Governance, Women's Leadership, Board Diversity, Corporate Values. 


\section{PENDAHULUAN}

Presentase jumlah pemimpin perempuan Indonesia pada suatu perusahaan pada tahun 2017 berdasarkan laporan hasil riset yang dirilis oleh Grant Thornton mengalami kenaikan yang sangat signifikan sebesar 36\% dari tahun 2016. Sebanyak 46\% wanita di Indonesia berhasil menduduki puncak kepemimpinan atau senior manajemen perusahaan. Riset tersebut dilakukan di 36 negara melalui interview dengan 5.500 CEO (Chief Excecutive Officer) managing director, chairman ataupun senior excecutive lainnya dari berbagai macam sektor industri. Hasil itu menempatkan Indonesia berada posisi dua terbesar dunia dalam hal kepemimpinan perempuan setelah Rusia yang memiliki proporsi sebesar $47 \%$ kemudian diposisi ketiga dan seterusnya ditempati oleh Estonia, Polandia dan Filipina dengan masing-masing proporsi sebesar 40\%. Grant Thornton menyebutkan secara detail posisi manajemen senior yang paling banyak dijabat oleh pemimpin perempuan di Indonesia ialah posisi CFO dengan proporsi 20\%, kemudian COO (14\%), CIO (8\%) dan CEO (6\%). (https://www.beritasatu.com, 2018).

Kehadiran perempuan dalam dewan direksi merupakan salah satu wujud dari keberagaman dewan. Keberagaman dewan juga sering dikenal dengan sebutan board diversity. Keberagaman dewan adalah salah satu tanda perusahaan memiliki tata kelola yang baik karena hal tersebut akan membuat perusahaan lebih menguntungkan dalam mengambil keputusan (Aluy dkk, 2017). Adanya keterlibatan perempuan dalam jajaran dewan perusahaan maupun dewan komisaris mencerminkan bahwa tidak adanya dekriminasi dalam perusahaan, artinya perusahaan memberikan kesempatan kepada siapapun untuk menjadi bagian dari dewan perusahaan, dengan begitu reputasi dan nilai perusahaan terhadap investor akan mengalami peningkatan (Kristina \& Wiratmaja, 2018).

Diterapkannya keberagaman dewan direksi dalam perusahaan merupakan positive signal yang ingin perusahaan tunjukkan kepada investor bahwa perusahaan tidak membeda-bedakan gender. Dengan keberagaman, akan tercipta kompetensi serta inovasi yang kemudian akan mendukung peningkatan kinerja perusahaan dan mempengaruhi nilai perusahaan. Keanekaragaman dewan memiliki pengaruh yang signifikan terhadap nilai perusahaan namun secara parsial keberadaan perempuan dalam dewan komisaris memiliki pengaruh negatif signifikan terhadap nilai perusahaan (Khairani, \& Harahap, 
2017; Kristina \& Wiratmaja, 2018). Ada beberapa alasan yang melatarbelakangi pengaruh negatif tersebut. Yang pertama, dalam penelitian ini kebanyakan perusahaan tidak memiliki anggota dewan komisaris perempuan. Kedua, Perusahaan yang terdaftar di BEI sebagian besar adalah bisnis keluarga dan keberadaan perempuan di dewan komisaris berdasarkan hubungan keluarga dengan pengendali pemegang saham bukan karena keterampilan atau pengalaman (Khairani, \& Harahap, 2017). Ketiga, adanya keragaman gender tidak memberikan perbedaan kinerja pada perusahaan (Kristina \& Wiratmaja, 2018)

Berbeda dengan hasil penelitian tersebut (Gordini \& Rancati, 2017; Gomez, 2018; Jubilee, et.al., 2018 Mintah-Agyemang \& Schadewitz, 2019;) menyebutkan bahwa keberadaan dewan perempuan memiliki dampak positif signifikan terhadap nilai perusahaan. Dengan keberagaman yang lebih besar maka potensi penghasilan perusahaan dimasa depan akan lebih efektif (Gordini \& Rancati, 2017). Perusahaan dengan keberagaman gender akan memiliki potensi yang lebihh besar karena tidak hanya memahami pasar tetapi juga hubungan eksternal sehingga akan lebih meningkatkan kreativitas dan inovasi perusahaan. (Jubilee, et.al., 2018). Selain itu, Kehadiran dewan perempuan dalam dewan direksi dapat meningkatkan independensi dewan dalam memantau perusahaan agar tidak menciptakan nilai bagi pemegang saham sehingga dapat merugikan yang lain (Carter, et al., 2003).

Resouce Dependence Theory menjelaskan bahwa perusahaaan sebagai badan organisasi saling tergantung dalam lingkungan bisnis dan membutuhkan konstituensi tertentu untuk membangun sumber daya eksternal untuk kinerja perusahaan (Pechersky, 2016). Tersedianya sumber daya termasuk modal manusia, pengalaman, pengetahuan baik laki-laki ataupun perempuan (Mintah-Agyemang \& Schadewitz, 2019) Artinya untuk memaksimalkan kinerja perusahaan, sumber daya yang dimiliki harus secara kritis dimanfaatkan agar memberikan dampak pada peningkatan nilai perusahaan. Dengan diterapkannya keberagaman gender dalam perusahaan memberikan dampak positif pada kinerja perusahaan (Li \& Chen, 2018) karena keberagaman gender pada dewan perusahaan tidak hanya bernilai etis tetapi juga ekonomis bagi perusahaan ( $\mathrm{Li} \&$ Chen, 2018) terutama bagi perusahaan dengan skala besar, mereka dapat mengambil 
keuntungan dari pengalaman, pengetahuan hingga nilai-nilai tertentu yang dimiliki perempuan.

Nilai perusahaan dapat diartikan sebagai persepsi investor terhadap keberhasilan perusahaan dalam mencapai tujuan saat ini serta prediksi perolehan keuntungan di masa yang akan datang. Nilai perusahaan yang tinggi merupakan keinginan semua pemilik perusahaan karena nilai perusahaan yang tinggi dapat menunjukkan kemakmuran pemegang sahamnya sehingga akan membuat investor menginvestasikan modalnya pada perusahaan (Mutmainnah, 2015). Investor akan memberikan ekspektasi tinggi terhadap perusahaan yang mampu mempertahankan nilainya di pasar begitupun sebaliknya (Sudana \& W Arlindania, 2011). Dalam meningkatkan citra dan nilai perusahaan, umumnya salah satu upaya yang dilakukan perusahaan ialah dengan melaksanakan Corporate social responsibility. Pelaksanaan kegiatan Corporate social responsibility akan memberikan respon yang positif dari masyarakat, daya beli masyarakatpun akan membaik serta akan menimbulkan kepedulian masyarakat terhadap produk yang dihasilkan perusahaan, artinya masyarakat secara tidak langsung memegang peranan yang penting dalam upaya peningkatan profitabiltas perusahaan (Ekasari \& Christine, 2012). Legistimasi Theory menjelaskan bahwa perusahaan diharuskan melaksanakan aktivitas Corporate social responsibility serta mengungkapkannya semaksimal mungkin dengan tujuan agar aktivitas yang dilakukan perusahaan mendapatkan legistimasi atau izin dari masyarakat sehingga kegiatan maupun produk perusahaan dapat diterima oleh masyarakat.

Agar legistimasi berjalan secara efektif maka salah satu upaya yang dilakukan perusahaan ialah dengan mengungkapkan segala aktivitas CSR yang telah dilakukan perusahaan. (Putra \& Wirakususma, 2017). Pengungkapan ini sifatnya suka rela karena belum ada regulator yang secara resmi mewajibkan perusahaan melakukan pengungkapan tentang aktivitas Corporate social responsibility perusahaan. Pengungkapan Corporate social responsibility yang dilakukan perusahaan bertujuan agar pihak-pihak yang berkepentingan dapat mengetahui bentuk tanggung jawab sosial yang telah dilakukan perusahaan sehingga dingkapkan dalam Annual Report perusahaan (Putra \& Wirakususma, 2017). Dengan dilakukannya pengungapan Corporate social responsibility 
maka diharapkan investor akan memperhatikan dan memberikan reaksi positif terhadap informasi-informasi yang telah diungkap karena perusahaan memperhatikan aspek sosialnya yang pada akhirnya perusahaan juga akan memperoleh manfaat berupa semakin disukainya produk yang dihasilkan perusahaan.

Prinsip signaling mengatakan "Action convey information", prinsip ini menggambarkan bahwa setiap tindakan yang dilakukan perusahaan mengandung sebuah informasi. Informasi tersebut merupakan pemberian sinyal kepada investor tentang keputusan-keputusan manajemen lalu direspon sebagai informasi yang positif. Sebagai wujud dari transparency, semua informasi yang dimiliki perusahaan baik berupa informasi keuangan maupun non keuangan harus diungkapkan perusahaan kepada seluruh stakeholdersnya sehingga tidak akan menimbulkan information asymmetry antara pihak internal dengan eksternal yang tidak memiliki informasi memadai untuk memonitoring tindakan pihak internal. Dalam annual report yang diterbitkan, perusahaan akan mengungkapkan informasi non keuangannya, salah satunya mengenai kegiatan Corporate social responsibility yang dilakukan perusahaan.

Pengungkapan aktivitas Corporate social responsibility perusahaan memiliki pengaruh positif yang signifikan terhadap nilai perusahaan, artinya besar kecilnya pelaksanaan Corporate social responsibility yang dilakukan perusahaan akan memberikan pengaruh terhadap peningkatan nilai perusahaan (Nahda \& Harjito, 2011; Rosiana, dkk, 2013; Setyowati, dkk 2014; Ardiyanto \& Haryanto, 2017; Bawafi \& Prastyo, 2018) hal tersebut disebabkan oleh beberapa hal, pertama informasi mengenai pertanggungjawaban sosial menimbulkan citra positif bagi masyarakat terutama dikalangan pebisnis karena disamping memperhatikan kepentingan shareholdernya, perusahaan juga memperhatikan kepentingan masyarakat sebagai konsumen dari produk yang akan dihasilkan perusahaan sehingga eksistensi perusahaan dapat dipertahankan kemudian akan menimbulkan peningkatan nilai perusahaan (Nahda \& Harjito, 2011). Kedua, Adanya pengungkapan Corporate Social Responsibility disclosure diharapkan akan memberikan nilai tambah perusahaan dalam menciptakan "Trust" para stakeholdersnya bahwa perusahaan akan terus berkembang serta berkelanjutan (Setyowati, dkk 2014). Ketiga, semakin luasnya Corporate Social Responsibility yang 
dilakukan perusahaan mengindikasikan bahwa perusahaan semakin memiliki perhatian terhadap aspek-aspek sosialnya. Hal seperti ini akan menjadi perhatian masyarakat serta pihak eksternal yang lain. Perhatian terhadap Corporate Social Responsibility nampaknya juga diperhatikan dan direspon positif oleh para investor (Ardiyanto \& Haryanto, 2017) dan yang keempat dengan Adanya praktik CSR yang baik, diharapkan akan memberikan citra yang baik pada pihak eksternal karena perusahaan tidak hanya beroperasi untuk kepentingan perusahaan namun juga memberikan manfaat bagi stakeholdernya. Dengan memperhatikan dimensi ekonomi, sosial maupun lingkungan nilai perusahaan akan terjamin tumbuh secara berkelanjutan (Bawafi \& Prastyo, 2018).

Hasil penelitian yang berbeda ditunjukkan oleh Mutmainah, 2015; Stacia \& Juniarti, 2015; Fajriana \& Priantinah, 2016; dan Putra \& Wirakusuma, 2017; Inastri \& Mimba, 2017. Penelitian mereka menyebutkan bahwa Corporate Social Responsibility disclosure tidak memiliki pengaruh signifikan terhadap nilai perusahaan. Hal itu disebabkan karena perusahaan tidak melakukan pengkomunikasian tanggung jawab sosial perusahaan secara tepat sehingga belum ditangkap secara tepat oleh piha-pihak yang berkepentingan. Sebagian besar perusahaan publik hanya berfokus pada faktor keuangan dan menganggap Corporate social responsibility hanyalah bersifat formalitas perusahaan. (Mutmainah, 2015). Selain itu, Stakeholder tidak begitu memperhatikan aktivitas CSR yang dilakukan perusahaan serta pelaporan CSR pun belum sepenuhnya dihargai oleh investor karena regulasi mengenai kewajiban pelaksanaan CSR di Indonesia yang baru dikeluarkan oleh pemerintah tahun 2007 yaitu Undang-Undang No 40 Tahun 2007 Pasal 74 tentang Tanggung Jawab Sosial dan Lingkungan Perseroan Terbatas (Stacia \& Juniarti, 2015). Penyebab kedua yaitu masih rendahnya kualitas pengungkapan yang dilakukan perusahaan serta belum sepenuhnya mengikuti standar yang dikeluarkan oleh GRI (Fajriana \& Priantinah, 2016). Yang ketiga ialah adanya reaksi negatif dari investor, dimana nilai perusahaan tidak akan terjamin tumbuh berkelanjutan dengan cara perusahaan memperhatikan dimensi ekonomi, sosial serta lingkungan hidup (Putra \& Wirakusuma, 2017).

Menurut Murwaningsari (2009) dalam Sudana \& W Arlindania (2011) Corporate Social Responsibility dan good corporate governance berkaitan erat, ibaratkan dua sisi mata uang keduanya memiliki kedudukan yang sama kuat dalam dunia bisnis namun 
berhubungan satu dengan yang lain. Corporate Social Responsibility berorientasi kepada para stakeholders, hal ini selaras dengan prinsip-prinsip good corporate governance yaitu prinsip responsibility adapun Corporate Social Responsibility Disclosure perusahaan selaras dengan prinsip transparency.

Good corporate governance merupakan faktor yang dapat memengaruhi nilai perusahaan (Nofiani dan Nurmayanti, 2010; M Retno \& Priantinah, 2012; Rendy \& Juniarti, 2013; Limanto \& Juniarti, 2014; Inastri \& Mimba, 2017). Perusahaan yang memiliki score good corporate governance tinggi mengindikasikan nilai perusahaannya juga tinggi begitu pula sebaliknya, perusahaan dengan score good corporate governance rendah mengindikasikan nilai perusahaannya juga rendah, hal ini disebabkan karena Good corporate governance dinilai berdasarkan transparency, accountability, predictability dan participation perusahaan dalam mengelola perusahaannya. Semakin besar score good corporate governance yang didapatkan perusahaan maka semakin baik pengelolaan yang dilakukan perusahaan, sehingga pencegahan terhadap adanya tindakan oportunistik manajemen yang dapat merugikan perusahaan juga semakin membaik. Namun berbeda dengan hasil penelitian yang dilakukan Mutmainnah 2015, hasilnya menyatakan bahwa good corporate governance memiliki pengaruh negatif terhadap nilai perusahaan. ia menyebutkan bahwa Praktek GCG yang dilakukan perusahaan memang dilaksanakan namun hal itu masih belum diterapkan secara maksimal oleh perusahaan artinya praktek GCG yan dilakukan perusahaan hanya bersifat formalitas untuk memenuhi kewajiban perusahaan pada peratauran yang telah ditetapkan oleh pemerintah sehingga investor pun menganggap praktek GCG bukanlah bahan pertimbangan dalam menilai perusahaan (Mutmainnah, 2015). Berbeda lagi dengan hasil penelitian Sukamulja (2004) yang menyebutkan bahwa Good Corporate Governance tidak memiliki pengaruh terhadap nilai perusahaan. Adapun penyebabnya yang pertama, sosialisasi mengenai pentingnya GCG kurang maksimal sehingga pihak manajemen perusahaan tidak melaksanakan GCG dengan baik ataupun melaksanakan namun tidak mengungkapkannya secara jelas. Kedua, GCG belum menjadi dasar utama investor dalam menganalisis perusahaan untuk melakukan investasi. Adanya ketidakkonsistenan hasil penelitian tentang Corporate Social Responsibility disclosure dan Scoring Good Corporate Governance terhadap nilai perusahaan tersebutlah yang menjadi alasan peneliti untuk 
menelitinya kembali dengan menggunakan kepemimpinan perempuan sebagai variabel moderating. Dimana moderasi ini jarang digunakan oleh peneliti yang lain.

\section{TINJAUAN PUSTAKA DAN PENGEMBANGAN HIPOTESIS}

\section{A. Pengaruh Corporate Social Responsibility Disclosure Terhadap Nilai Perusahaan}

Nilai perusahaan tidak akan tumbuh berkelanjutan jika perusahaan hanya memperhatikan kondisi keuangannya semata. Keberlanjutan perusahaan baru akan terjamin apabila perusahaan memperhatikan dua dimensi yang mengelilinginya yaitu dimensi keuangan serta dimensi sosial dan lingkungan hidupnya (Nahda \& Harjito, 2011).

Legistimasi Theory menjelaskan bahwa perusahaan diharuskan melaksanakan aktivitas Corporate social responsibility dengan tujuan agar aktivitas yang dilakukan perusahaan mendapatkan legistimasi atau izin dari masyarakat sehingga kegiatan maupun produk perusahaan diterima oleh masyarakat.

Dengan dilakukannya pengungapan Corporate social responsibility maka diharapkan investor akan memperhatikan dan memberikan reaksi positif terhadap informasi-informasi yang telah diungkap karena perusahaan memperhatikan aspek sosialnya yang pada akhirnya perusahaan juga akan memperoleh manfaat berupa semakin disukainya produk yang dihasilkan perusahaan. Prinsip signaling mengatakan "Actions Convey Information" (Atmaja, 2008:6). Prinsip ini mengandung arti bahwa setiap tindakan yang dilakukan perusahaan mengandung sebuah informasi. Informasi ini merupakan pemberian sinyal kepada investor tentang keputusan-keputusan manajemen. Secara spesifik Scott (2009:457) dalam penelitian Salman dkk (2014) menjelaskan bahwa sinyal yang disampaikan oleh manajer dapat berupa pengungkapan secara terperinci dan lengkap yang diungkap melalui annual reportnya. Pengungkapan yang seperti itulah akan mengurangi kesenjangan informasi dan pengurangan biaya agensi tata kelola perusahaan sehingga dapat menjadi penentu peningkatan kinerja perusahaan kemudian investor akan mempersepsikan perusahaan tersebut berkinerja baik. Pengungkapan yang wajib diungkap oleh perusahaan salah satunya ialah mengenai aktivitas Corporate Social Responsibility perusahaan (M. Retro \& Priantinah, 2012). 
Dalam penelitian Sudana \& W Arlindania (2011), Mathews (1995) menjelaskan bahwa pengungkapan tanggung jawab sosial adalah proses penginformasian dampak sosial serta lingkungan akibat kegiatan ekonomi perusahaan terhadap masyarakat. Pengungkapan tanggung jawab sosial ini juga sering dikenal sebagai social disclosure, corporate social reporting dan social accounting. Salah satu motivasi dari pengungkapan mengenai lingkungan dan sosial adalah untuk meningkatkan properti semua pemegang saham (Mirfazli, 2008). Positive Accounting Theory menjelaskan bahwa setiap orang melakukan kegiatan karena didorong oleh tercapainya suatu kepentingan pribadi (Mirfazli, 2008). Jika setiap orang memiliki keinginan untuk memenuhi kepentingan pribadinya, maka dengan melakukan pengungkapan informasi mengenai lingkungan dan sosial mereka berharap akan mendapatkan peningkatan properti atas aktivitas pengungkapan tersebut. Peningkatan properti yang dimaksud ialah peningkatan laba atau nilai perusahaan (Mirfazli, 2008).

Meningkatkan nilai perusahaan dimata investor merupakan tujuan utama setiap perusahaan. dimana nilai perusahaan akan terlihat melalui harga saham perusahaan. (Putra dan Wirakusuma, 2017). Apabila perusahaan ingin nilai perusahaannya tetap tumbuh berkelanjutan maka perusahaan harus menyeimbangkan antara kepentingankepentingan yang ada yaitu ekonomi, lingkungan dan masyarakat (Putra dan Wirakusuma, 2017). Menyeimbangkan banyak kepentingan itu bisa diwujudkan dengan melakukan tanggung jawab sosial, hal itu dilakukan sebagai bentuk rasa tanggung jawab dan kepedulian perusahaan terhadap lingkungan sosialnya (Putra dan Wirakusuma, 2017). Tata kelola yang efektif akan memastikan bahwa kepentingan pemegang saham terpelihara, oleh karena itu mengenai kinerja ekonomi, sosial, lingkungan harus dilaporkan kepada para stakeholder dan Corporate social responsibility mendukung triple bottom line tersebut (Said et.al., 2009).

Corporate social responsibility disclosure yang dilakukan perusahaan memiliki pengaruh terhadap nilai perusahaan (Nahda \& Harjito, 2011; Rosiana, dkk, 2013; Setyowati, dkk 2014; Ardiyanto \& Haryanto, 2017; Bawafi \& Prastyo, 2018). Salah satu pengukuran Corporate social responsibility disclosure adalah Global Reporting Index (GRI). Secara umum kerangka pelaporan GRI melaporkan kinerja ekonomi, lingkungan dan sosial dari organisasi (Sudana \& W Arlindania, 2011). Berdasarkan teori dan 
penelitian diatas maka rumusan hipotesis pertama yang diajukan dalam penelitian ini ialah:

H1: Corporate social responsibility disclosure memiliki pengaruh positif terhadap nilai perusahaan

\section{B. Pengaruh Scoring Good Corporate Governance Terhadap Nilai Perusahaan}

Scoring good corporate governance merupakan representasi yang digunakan dalam menilai seberapa baik perusahaan dalam menerapkan good corporate governance. Tujuan utama dari pengelolaan perusahaan yang baik yaitu memberikan perlindungan dan perlakuan yang adil kepada pemegang saham dan stakeholder lainnya melalui memaksimalkan peningkatan nilai. (Emirzon, 2006) Pengelolaan yang baik bukan hanya sekedar upaya menjaga agar perusahaan bekerja sesuai norma dan peraturan yang berlaku namun pengelolaan perusahaan yang baik itu diketahui oleh publik dan para stakeholders sehigga mereka benar-benar yakin dan percaya atas investasinya. Semakin tinggi score good corporate governance yang diperoleh perusahaan maka nilai perusahaan juga semakin tinggi dan begitu sebaliknya (Nofiani dan Nurmayanti, 2010; M Retno \& Priantinah, 2012; Rendy \& Juniarti, 2013; Limanto \& Juniarti, 2014; Inastri \& Mimba, 2017).

Che Haat et al., (2008) dalam Inastri dan Mimba (2017) mengatakan bahwa dalam meningkatkan kepercayaan investor, perusahaan harus memiliki tata kelola perusahaan yang baik karena dengan begitu laporan keuangan, pengungungkapan dan pelaporan bisnisnya akan menjadi lebih transparan. Dengan diterapkannya good corporate governance modal yang ditanamkan investor kedalam sebuah perusahaan tersebut akan terjamin serta dapat dipertanggungjawabkan. Good corporate governance dipersepsikan sebagai hal yang positif oleh investor karena fungsinya sebagai sistem pengendali dalam perusahaan, sistem tata kelola perusahaan yang baik mampu mengatur keadaan perusahaan serta dapat mengurangi terjadinya konflik keagenan dalam perusahaan (Randy dan Juniarti, 2013). Selain itu Nuswandari (2009) dalam Randy dan Juniarti (2013) menyebutkan bahwa good corporate governance dapat meningkatakan efisiensi perusahaan serta memungkinkan terwujudnya pembagian keuntungan yang merata diantara para stakeholder. 
Manfaat dari tata kelola yang baik akan tampak dari ketersediaan investor dalam membayar ekuitas perusahaan melalui harga sahamnya (Inastri dan Mimba, 2017). Jika harga saham yang tinggi bersedia dibayar oleh investor maka hal itu menandakan bahwa praktek good corporate governance yang diterapkan perusahaan juga tinggi. Persepsi positif itulah yang akhirnya membuat investor bereaksi positif sehingga akan membuat harga saham akan meningkat.(Randy dan Juniarti, 2013).

Penilaian seberapa baik perusahaan dalam menerapkan good corporate governancenya diukur menggunakan scoring good corporate governance. (Nofiani dan Nurmayanti, 2010; M Retno \& Priantinah, 2012; Randy dan Juniarti, 2013; Rendy \& Juniarti, 2013; Inastri \& Mimba, 2017). Perusahaan dengan score good corporate governance yang tinggi maka nilai perusahaannya juga akan tinggi begitu sebaliknya. hal ini disebabkan karena Good corporate governance dinilai berdasarkan transparency, accountability, predictability dan participation perusahaan dalam mengelola perusahaannya. Semakin tinggi score good corporate governance yang didapatkan perusahaan maka mengindikasikan semakin tinggi atau semakin baik pula pengelolaan yang dilakukan perusahaan untuk mencegah adanya tindakan oportunistik manajemen yang dapat merugikan perusahaan. Sehingga rumusan hipotesis kedua yang diajukan dalam penelitian ini ialah:

H2: Scoring Good corporate governance memiliki pengaruh positif terhadap nilai perusahaan

\section{Peran Kepemimpinan Perempuan Dalam Memoderasi Pengaruh Corporate Social Responsibility Disclosure Terhadap Nilai Perusahaan}

Adanya keterlibatan perempuan dalam jajaran dewan perusahaan mencerminkan bahwa tidak adanya deskriminasi dalam perusahaan tersebut, artinya perusahaan memberikan kesempatan kepada siapapun untuk menjadi bagian dari dewan perusahaan, tentunya hal itu akan meningkatkan reputasi dan nilai perusahaan terhadap investor (Kristina \& Wiratmaja, 2018). Diterapkannya keberagaman dewan direksi dalam perusahaan merupakan positive signal yang ingin perusahaan tunjukkan kepada investor bahwa perusahaan tidak membeda-bedakan gender. Adams dan Ferreira (2004) dalam Sudana dan W Arlindania (2011) menyatakan bahwa Perusahaan dengan dewan direksi 
yang heterogen jauh memberikan hasil yang lebih sukses dari pada perusahaan dengan dewan direksi yang homogen karena dengan kehadiran dewan direksi perempuan akan memberikan pola tersendiri pada perusahaan.

Kehadiran dewan perempuan di dalam perusahaan dapat meningkatkan kemampuan perusahaan tersebut dalam menerapkan strategi yang lebih baik untuk mengatasi ekonomi, sosial dan kendala lingkungan serta membuat investor bereaksi positif (Loukil et. al., 2019). Perusahaan yang memiliki keragam gender lebih besar dalam dewan eksekutif dan top manajemen puncak dapat berkinerja lebih baik dari pada perusahaan dengan keanekaragamanan gender yang lebih rendah (Luis-Carnicer. et.al., 2008).

Resouce Dependence Theory menjelaskan bahwa perusahaaan sebagai badan organisasi saling tergantung dalam lingkungan bisnis dan membutuhkan konstituensi tertentu untuk membangun sumber daya eksternal untuk kinerja perusahaan (Pechersky, 2016). Tersedianya sumber daya termasuk modal manusia, pengalaman, pengetahuan baik laki-laki ataupun perempuan (Mintah-Agyemang \& Schadewitz, 2019). Dewan perusahaan dianggap sebagai sumber daya strategi yang meningkatkan nilai perusahaan melalui membina interaksi lembaga dengan sumber daya eksternalnya (Jubilee, et.al., 2018). Kehadiran perempuan di manajemen puncak memiliki dampak yang positif terhadap kinerja perusahaan (Gomez, 2018) sebab perusahaan mempunyai kualitas struktur organisasi dengan mengekploitasi sumber daya yang dimiliki berupa keragaman gender untuk menghasilkan keuntungan.

Keanekaragaman dewan memiliki pengaruh yang signifikan terhadap nilai perusahaan (Gordini \& Rancati, 2017) Namun secara parsial keberadaan dewan komisaris perempuan memiliki pengaruh yang negatif signifikan terhadap nilai perusahaan (Kusmatuti dkk, 2007; Darmadi, 2013; Khairani, \& Harahap, 2017;) Berbeda dengan hasil penelitian tersebut (Gordini \& Rancati, 2017; Gomez, 2018; Mintah-Agyemang \& Schadewitz, 2019) menyebutkan bahwa keberadaan dewan perempuan pada perusahaan memiliki dampak yang positif signifikan terhadap nilai perusahaan. Berdasarkan teori dan penelitian diatas rumusan hipotesis ketiga dari penelitian ini ialah: 
H3: Kepemimpinan perempuan berperan memperkuat atau memperlemah pengaruh antara corporate social responsibility disclosure dengan nilai perusahaan

\section{Peran Kepemimpinan Perempuan dalam Memoderasi Pengaruh Scoring Good Corporate Governance Terhadap Nilai Perusahaan}

Agency Theory merupakan teori yang menjaskan tentang adanya hubungan kontraktual antara hubungan prinsipal dengan agent. Sebagai agent, perusahaan akan mengoptimalkan perolehan keuntungan yang akan didapat oleh pemilik (partisipal). Agen harus bertindak rasional dalam memenuhi kepentingan partisipalnya, agen juga harus bijaksana, memiliki i'tikad baik, tingkah laku yang wajar serta adil dalam memimpin perusahaan (Khairandy \& Malik, 2007:17). Keragaman dalam direksi sebagai solusi masalah keagenan antara agen dengan partisipal. kehadiran perempuan dapat menjadi alat kontrol serta meningkatkan independensi dewan dalam memantau perusahaan agar tidak menciptakan nilai bagi pemegang saham yang dapat merugikan yang lain (Carter, et al., 2003).

Dengan kehadiran perempuan dalam perusahaan, maka perusahaan dianggap telah menerapkan praktek tata kelola yang baik. Keterlibatan perempuan dalam dalam jajaran dewan dan dewan komisaris perusahaan mencerminkan tidak adanya deskriminasi dalam perusahaan, artinya perusahaan memberikan kesempatan kepada siapapun untuk menjadi bagian dari dewan perusahaan, persepsi itu yang akan meningkatkan reputasi dan

nilai perusahaan terhadap investor (Kristina \& Wiratmaja, 2018). Semakin baik perusahaan menerapkan praktek good corporate governance maka akan semakin baik pula perusahaan dalam meningkatkan kinerja pasarnya sehingga kemampuan perusahaan dalam menghasilkan earning dengan rate of return yang sesuai dengan harga perolehan aset-asetnya juga akan mengalami peningkatan (Nofiani dan Nurmayanti, 2010). Hal ini tentu juga akan berdampak pada kelangsungan hidup perusahaan, kesejahteraan karyawan maupun pemegang saham (Nofiani dan Nurmayanti, 2010).

Dalam hal memipin, gaya kepemimpinan yang digunakan perempuan yaitu kepemimpinan kolaboratif, dengan tipe kepemimpinan ini akan memberikan keuntungan pada dewan direksi melalui peningkatan mendengarkan inovasi, keluhan karyawan, dukungan sosial, dan penggunaan strategi win-win solution (Sudana dan W Arlindania, 
2011). Kehadiran perempuan memastikan bahwa prosedur pemantauan dan pengawasan yang diikuti tepat sehingga akan memberikan kinerja keuangan yang lebih baik (MintahAgyemang \& Schadewitz 2019). Sikap kehati-hatian tinggi yang dimiliki perempuan dan lebih cenderung menghindari risiko (risk avoidance) serta lebih teliti jika dibandingkan dengan laki-laki yang membuat perempuan tidak terburu-buru dalam mengambil suatu keputusan (Sudana dan W Arlindania, 2011). Dengan adanya wanita di dalam jajaran direksi dapat membantu dalam hal pengambilan keputusan yang lebih tepat dan memiliki risiko yang lebih rendah. Keberadaan dewan wanita pada perusahaan memiliki dampak positif signifikan terhadap nilai perusahaan (Gordini \& Rancati, 2017; Gomez, 2018; Mintah-Agyemang \& Schadewitz, 2019) Berdasarkan argumentasi dan hasil penelitian diatas maka hipotesis keempat yang diajukan dalam penelitian ini ialah:

H4: Kepemimpinan perempuan berperan memperkuat atau memperlemah pengaruh antara scoring good corporate governance dengan nilai perusahaan.

\section{METODE PENELITIAN}

Penelitian ini merupakan penelitian deskriptif kuantitatif. Populasi dari penelitian ini adalah seluruh perusahaan yang terdaftar di BEI pada Sub sektor Bank periode 20152018. Sampel penelilitian ini berjumlah 18 perusahaan dengan teknik pengambilan sampel purposive sampling. Adapun kriteria-kriteria purposive sampling yang pertama, seluruh perusahaan yang terdaftar di BEI pada Sub sektor Bank periode 2015-2018. Kedua, perusahaan yang secara konsisten memiliki direktur perempuan selama periode pengamatan. Ketiga, perusahaan yang mengungkapkan aktivitas tanggung jawab sosialnya dan yang keempat, perusahaan yang mengungkapkan score GCG berupa self assessment perusahaan yang meliputi 5 subindex (Pemegang Saham, Dewan Komisaris, Komisaris Independen, Komite Audit dan Audit Internal, dan Pengungkapan kepada Investor). Data dikumpulkan dari berbagai sumber yaitu dari Annual Report, Sustainability report, Company Report hingga web resmi milik perusahaan.

Berikut adalah 18 daftar sampel penelitian yaitu Bank MNC Internasional (BABP), Bank Cental Asia (BBCA), Bank Negara Indonesia (BBNI), Bank Rakyat Indonesia (BBRI), Bank Danamon Indonesia (BDMN), Bank Ina Perdana (BINA), Bank 
Jabar Banten (BJBR), Bank Mandiri (BMRI), Bank CIMB Niaga (BNGA), Bank Maybank Indonesia (BNII), Bank Permata (BNLI), Bank Tabungan Pensiunan Nasional (BTPN), Bank Artha Graha International (INPC), Bank Mayapada International (MAYA), Bank China Construction Bank Ind. (MCOR), Bank Mega (MEGA), Bank OCBC NISP (NISP), dan Bank Pan Indonesia (PNBN). Adapun metode analisisnya menggunakan Moderate Regression Analysis (MRA).

Variabel Independen penelitian ini terdiri dari corporate social responsibility disclosure dan scoring good corporate governance. Corporate social responsibility disclosure diukur melalui Global Reporting Initiative (GRI). GRI digunakan dalam melaporkan kinerja berkelanjutan dari sebuah organisasi baik itu kinerja ekonomi, lingkungan dan sosial dari organisasi. Adapun GRI yang digunakan dalam penelitian ini adalah GRI G4.

Terdapat 7 Indikator yang dapat digunakan untuk mengukur pengungkapan CSR di Indonesia menurut Eddy Rismanda Sembiring (2005) yang diadopsi dari penelitian Hackston dan Milne (1996) dalam Sudana dan W Arlindania (2011) yaitu lingkungan, energi, kesehatan dan keselamatan tenaga kerja, lain-lain tenaga kerja, produk, keterlibatan masyarakat dan umum. Berdasarkan peraturan Bapepam No. VIII.G.2 tentang laporan tahunan dan kesesuaian item-item untuk diaplikasikan di Indonesia maka dilakukan dilakukan penyesuaian dengan kondisi indonesia sehingga tersisia 78 item pengungkapan, 12 item dihapuskan karena kurang sesuai untuk diterapkan dengan kondisi di Indonesia. Kemudian skala pengukuran untuk pengungkapan CSR menggunakan dummy variable . Jadi setiap item CSR dalam instrumen penelitian jika diungkapkan akan diberi nilai 1 sedangkan jika tidak diungkapkan akan diberi nilai 0 . Lalu skor dari tiap-tiap item akan dijumlahkan untuk memperoleh skor keseluruhan yang mewaliki setiap perusahaan (Sudana dan W Arlindania, 2011). Adapun rumus yang digunakan untuk menghitung corporate social responsibility disclosure sebagai berikut :

$$
\text { CSRDI }=\frac{\varepsilon X i j}{\text { Jumlah Item Pengungkapan }}
$$

\section{Keterangan:}

CSRDij $\quad$ : Corporate Social Responsibility Index perusahaan $\mathrm{j}$

Xij $\quad$ : Dummy variable (Jika diungkapkan akan diberi nilai 1 namun jika tidak diungkapkan akan diberi nilai 0) 
Sedangkan scoring good corporate governance diukur menggunakan 5 subindex yaitu Hak pemegang saham, dewan komisaris, komisaris independen, komite audit dan audit internal, dan pengungkapan kepada investor (Limanto \& Juniarti, 2014). 5 sub index tersebut dapat diketahui melalui self assessment perusahaan yang diungkapkan melalui laporan GCG perusahaan. Semakin mendekati angka 1 maka semakin baik perusahaan dalam menerapkan good corporate governance. Adapun variabel dependen dari peneilitian ini adalah nilai perusahaan yang diproksikan melalui Tobin's Q (Istikhoroh \& Suhardiyah, 2016). Menghitung besarnya Tobin's Q sebagai berikut:

$$
\mathrm{TQ}=\frac{E M V+D}{E B V+D}
$$

\section{Keterangan:}

EMV = Nilai Pasar Ekuitas (closing price $\mathrm{x}$ jumlah saham beredar)

$\mathrm{D} \quad=$ Nilai buku Total Hutang

$\mathrm{EBV} \quad=$ Nilai Buku Total Ekuitas

Variabel terakhir yang digunakan pada penelitian ini yaitu variabel kepemimpinan perempuan yang ditempatkan sebagai variabel moderasi (Proporsi dewan direksi Perempuan) yang diukur melalui variabel dummy, Jika terdapat dewan direksi perempuan maka diberi nilai 1 namun jika terdapat dewan direksi perempuan akan diberi nilai 0 (Sudana dan W Arlindania, 2019).

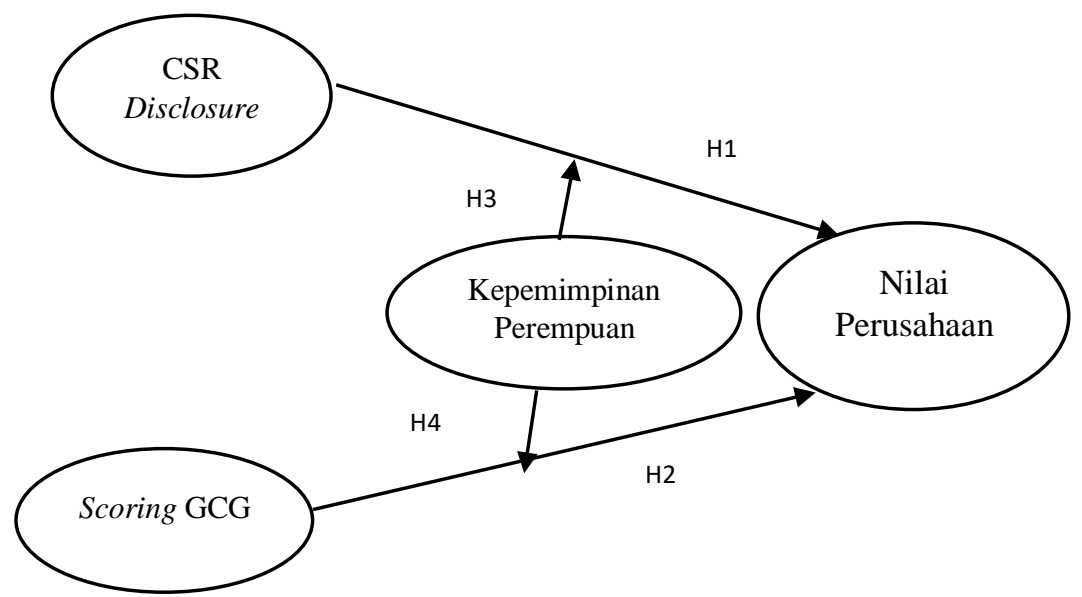

Gambar 1. Kerangka Penelitian 


\section{HASIL DAN PEMBAHASAN}

\section{A. Hasil}

Berikut ini adalah hasil dari penelitian ini:

1) Hasil Uji Parsial (Uji t)

\section{Tabel 1}

Tabel Coeficients Uji Parsial (Uji t)

\begin{tabular}{|c|c|c|c|c|c|c|}
\hline & & \multicolumn{2}{|c|}{$\begin{array}{c}\text { Unstandardized } \\
\text { Coefficients }\end{array}$} & \multirow{2}{*}{$\begin{array}{c}\begin{array}{c}\text { Standardized } \\
\text { Coefficients }\end{array} \\
\text { Beta } \\
\end{array}$} & \multirow[b]{2}{*}{$\mathrm{T}$} & \multirow[b]{2}{*}{ Sig. } \\
\hline \multicolumn{2}{|c|}{ Model } & $\mathrm{B}$ & Std. Error & & & \\
\hline \multirow[t]{2}{*}{1} & (Constant) & .016 & .108 & & .144 & .887 \\
\hline & Lag_CSRD & 1.237 & .809 & .367 & 1.528 & .147 \\
\hline \multirow[t]{2}{*}{2.} & (Constant) & .478 & .127 & & 3.775 & .002 \\
\hline & $\begin{array}{l}\text { Lag_Score } \\
\text { GCG }\end{array}$ & -.263 & .100 & -.562 & -2.633 & .019 \\
\hline \multicolumn{4}{|c|}{ a. Dependent Variable: Lag_TobinsQ } & & & \\
\hline
\end{tabular}

Sumber: Data diolah Peneliti (2019)

Berdasarkan hasil output Tabel 1 setelah distandarkan menggunakan lag (1) maka diperoleh t hitung CSRD sebesar 1.528 lebih kecil dari t tabel 2.100 sedangkan tingkat signifikansi sebesar 0.147 lebih besar dari 0.05 maka dapat disimpulkan bahwa CSRD tidak berpengaruh terhadap nilai perusahaan sehingga hipotesis pertama yang diajukan pada penelitian ini ditolak sedangkan t hitung Scoring GCG sebesar -2.633 lebih kecil dari t tabel 2.100 dengan tingkat signifikansi sebesar 0.019 lebih kecil dari 0.05 maka dapat disimpulkan bahwa Scoring GCG berpengaruh negatif terhadap nilai perusahaan sehingga hipotesis pertama yang diajukan pada penelitian ini diterima.

Tabel 2

Tabel Koefisien Determinasi Uji Parsial (Uji t)

\begin{tabular}{|l|r|r|r|r|}
\hline \multicolumn{7}{|c|}{ Model Summary $^{\mathbf{b}}$} \\
\hline 1 & $\mathrm{R}$ & \multicolumn{1}{|c|}{ R Square } & \multicolumn{1}{c|}{ Adjusted R Square } & Std. Error of the Estimate \\
\hline 2 & $.367^{\mathrm{a}}$ & .135 & .077 & .19499 \\
\hline \multicolumn{2}{|l|}{ a. Predictors: (Constant), Lag_CSRD, } & .270 & .17335 \\
\hline \multicolumn{2}{|l|}{ b. Predictors: (Constant), Lag_ScoreGCG } \\
\hline \multicolumn{2}{|l|}{ b. Dependent Variable: Lag_TobinsQ } \\
\hline
\end{tabular}


Sumber: Data diolah Peneliti (2019)

Hasil Output Tabel 2 menunjukkan bahwa nilai $R$ square CSRD sebesar 0.135 dan $R$ square Score Good Corporate Governance 0.316. Artinya kemampuan variabel CSRD mampu menjelaskan pengaruh sebesar 13,5\% terhadap nilai perusahaan (TobinsQ) sedangkan variabel Score Good Corporate Governance mampu menjelaskan pengaruh sebesar 31,6\% terhadap nilai perusahaan (TobinsQ) sedangkan sisanya sebesar 54,9\% dijelaskan oleh variabel independent lain diluar model penelitian ini.

\section{2) Hasil Uji Moderasi (MRA)}

Tabel 3.

Tabel Coeficients Setelah Melibatkan Moderasi

\begin{tabular}{|c|c|c|c|c|c|c|}
\hline \multirow{2}{*}{\multicolumn{2}{|c|}{ Model }} & \multicolumn{2}{|c|}{ Unstandardized Coefficients } & \multirow{3}{*}{$\begin{array}{c}\begin{array}{c}\text { Standardized } \\
\text { Coefficients }\end{array} \\
\text { Beta } \\
\end{array}$} & \multirow{3}{*}{$\begin{array}{l}\mathrm{T} \\
.906\end{array}$} & \multirow{3}{*}{$\begin{array}{r}\text { Sig. } \\
.380\end{array}$} \\
\hline & & \multirow{2}{*}{$\begin{array}{ll}\mathrm{B} & \\
.125\end{array}$} & \multirow{2}{*}{$\begin{array}{r}\text { Std. Error } \\
.139\end{array}$} & & & \\
\hline \multirow[t]{3}{*}{1} & (Constant) & & & & & \\
\hline & Lag_CSRD & .979 & .823 & .291 & 1.191 & .254 \\
\hline & Lag_DDW & -.455 & .369 & -.301 & -1.233 & .238 \\
\hline \multirow[t]{3}{*}{2.} & (Constant) & .485 & .129 & & 3.765 & .002 \\
\hline & $\begin{array}{l}\text { Lag_ScoreGC } \\
\text { G }\end{array}$ & -.230 & .111 & -.491 & -2.076 & .057 \\
\hline & Lag_DDW & -.269 & .358 & -.178 & -.752 & .464 \\
\hline \multicolumn{4}{|c|}{ a. Dependent Variable: Lag_TobinsQ } & & & \\
\hline
\end{tabular}

Pada tahap kedua, hasil output Tabel 3 diperoleh nilai signifikansi CSRD terhadap nilai perusahaan (Tobin's Q) setelah melibatkan variabel dewan direksi perempuan sebesar 0.254 lebih besar dari 0.05 artinya variabel CSRD tidak signifikan terhadap nilai perusahaan sedangkan nilai signifikansi Score GCG terhadap nilai perusahaan (Tobin's Q) setelah adanya melibatkan variabel dewan direksi perempuan sebesar 0.057 lebih besar dari 0.05 artinya setelah melibatkan variabel direksi perempuan menjadi tidak signifikan terhadap nilai perusahaan. 
Tabel 4

Hasil Uji Koefesien Determinasi Setelah Melibatkan Moderasi

\begin{tabular}{|c|c|c|c|c|}
\hline \multicolumn{5}{|c|}{ Model Summary $^{\mathbf{b}}$} \\
\hline Model & $\mathrm{R}$ & R Square & Adjusted R Square & Std. Error of the Estimate \\
\hline 1 & $.468^{\mathrm{a}}$ & .219 & .108 & .19170 \\
\hline 2 & $.585^{\mathrm{a}}$ & .343 & .249 & .17591 \\
\hline \multicolumn{5}{|c|}{ a. Predictors: (Constant), Lag_DDW, Lag_CSRD, } \\
\hline \multicolumn{4}{|c|}{$\begin{array}{l}\text { b. Predictors: (Constant), Lag_ScoreGCG, } \\
\text { Lag_DDW }\end{array}$} & \\
\hline b. Depe & ent & riable: Lag_- & obinsQ & \\
\hline
\end{tabular}

Sumber: Data diolah Peneliti (2019)

Hasil Output tahap kedua Tabel 4 menunjukkan bahwa nilai $R$ square CSRD setelah melibatkan variabel dewan direksi perempuan menjadi sebesar 0.219 dan $R$ square Score Good Corporate Governance 0.343. Artinya kemampuan variabel CSRD setelah melibatkan variabel dewan direksi perempuan mampu menjelaskan pengaruh sebesar 21.9\% terhadap nilai perusahaan (Tobins Q) sedangkan variabel Score Good Corporate Governance setelah melibatkan variabel dewan direksi perempuan mampu menjelaskan pengaruh sebesar 34.3\% terhadap nilai perusahaan (Tobins Q).

\section{Tabel 5}

Tabel Coeficients Setelah Melibatkan Interaksi Variabel X dengan Z

\begin{tabular}{|c|c|c|c|c|c|c|}
\hline \multicolumn{2}{|r|}{ 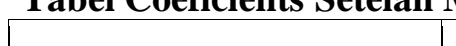 } & \multirow{2}{*}{\multicolumn{2}{|c|}{\begin{tabular}{c|c} 
Unstandardized \\
Coefficients
\end{tabular}}} & \multirow{3}{*}{\begin{tabular}{|c|}
$\begin{array}{c}\text { Standardized } \\
\text { Coefficients }\end{array}$ \\
Beta \\
\end{tabular}} & \multirow[b]{3}{*}{$\mathrm{T}$} & \multirow[b]{3}{*}{ Sig. } \\
\hline & & & & & & \\
\hline \multicolumn{2}{|c|}{ Model } & $\mathrm{B}$ & Std. Error & & & \\
\hline \multirow[t]{4}{*}{1} & (Constant) & .514 & .152 & & 3.384 & .005 \\
\hline & Lag_CSRD & -2.470 & 1.164 & -.733 & -2.122 & .054 \\
\hline & Lag_DDW & -2.948 & .766 & -1.950 & -3.849 & .002 \\
\hline & LagCSRDxLagDDW & 24.224 & 6.945 & 1.814 & 3.488 & .004 \\
\hline \multirow[t]{3}{*}{2} & (Constant) & .571 & .191 & & 2.995 & .010 \\
\hline & Lag_ScoreGCG & -.286 & .145 & -.611 & -1.978 & .070 \\
\hline & Lag_DDW & -1.477 & 1.966 & -.977 & -.751 & .466 \\
\hline
\end{tabular}




\begin{tabular}{|l|l|r|r|r|r|}
\hline $\begin{array}{l}\text { LagScoreGCGxLag } \\
\text { DDW }\end{array}$ & .833 & 1.332 & .866 & .626 & .542 \\
\hline a. Dependent Variable: Lag_TobinsQ & & & & \\
\hline
\end{tabular}

Sumber: Data diolah Peneliti (2019)

Berdasarkan hasil output pada tabel 5 diperoleh nilai signifikansi CSRD terhadap nilai perusahaan (Tobin's Q) setelah melibatkan interaksi variabel CSRD dengan dewan direksi perempuan sebesar 0.054 lebih kecil dari 0.05 artinya pada tahap ini variabel CSRD menjadi signifikan sedangkan nilai signifikansi Score GCG terhadap nilai perusahaan (Tobin's Q) setelah melibatkan interaksi variabel Score GCG dengan dewan direksi perempuan sebesar 0.070 lebih besar dari 0.05 artinya pada tahap ini variabel Score GCG menjadi tidak signifikan. Karena adanya perbedaan hasil signifikansi pada tahap kedua dan ketiga maka variabel moderasi yang digunakan dalam penelitian ini yaitu variabel dewan direksi perempuan mempunyai peranan sebagai variabel pure moderasi.

Tabel 6

Tabel Koefesien Determinasi Setelah Melibatkan Interaksi

\begin{tabular}{|c|c|c|c|c|}
\hline \multicolumn{5}{|c|}{ Model Summary ${ }^{b}$} \\
\hline Model & $\mathrm{R}$ & R Square & Adjusted R Square & Std. Error of the Estimate \\
\hline 1 & $.772^{\mathrm{a}}$ & .597 & .504 & .14298 \\
\hline 2 & $.602^{\mathrm{a}}$ & .362 & .215 & 17986 \\
\hline \multicolumn{4}{|c|}{$\begin{array}{l}\text { a. Predictors: (Constant), LagCSRDxLagDDW, Lag_CSRD, } \\
\text { Lag_DDW }\end{array}$} & \\
\hline \multicolumn{4}{|c|}{$\begin{array}{l}\text { b. Predictors: (Constant), LagScoreGCGxLagDDW, } \\
\text { Lag_ScoreGCG, Lag_DDW }\end{array}$} & \\
\hline \multicolumn{4}{|c|}{ c. Dependent Variable: Lag_TobinsQ } & \\
\hline
\end{tabular}

Hasil Output tahap ketiga pada Tabel 6 menunjukkan bahwa nilai $R$ square CSRD setelah melibatkan interaksi variabel CSRD dengan dewan direksi perempuan menjadi sebesar 0.597 atau $59.7 \%$ artinya variabel dewan direksi perempuan mempunyai peranan sebagai variabel moderasi yang dapat memperkuat hubungan antara variabel CSRD dengan nilai perusahaan (Tobin's Q) maka dapat disimpulkan bahwa hipotesis ke 
tiga penelitian ini diterima sedangkan nilai $R$ square Score Good Corporate Governance setelah melibatkan interaksi variabel Score GCG dengan dewan direksi perempuan menjadi 0.362 atau $36.2 \%$ artinya variabel dewan direksi perempuan juga mempunyai peranan sebagai variabel moderasi yang dapat memperkuat hubungan antara variabel Score GCG dengan nilai perusahaan (Tobin's Q) maka dapat disimpulkan bahwa hipotesis ke empat penelitian ini diterima.

\section{B. Pembahasan}

\section{Pengaruh Corporate Social Responsibility Disclosure Terhadap Nilai Perusahaan}

Nilai perusahaan tidak akan tumbuh berkelanjutan jika perusahaan hanya memperhatikan kondisi keuangannya semata. Keberlanjutan perusahaan baru akan terjamin apabila perusahaan memperhatikan dua dimensi yang mengelilinginya yaitu dimensi keuangan serta dimensi sosial dan lingkungan hidupnya (Nahda \& Harjito, 2011). Legistimasi Theory menjelaskan bahwa perusahaan diharuskan melaksanakan aktivitas Corporate social responsibility dengan tujuan agar aktivitas yang dilakukan perusahaan mendapatkan legistimasi atau izin dari masyarakat sehingga kegiatan maupun produk perusahaan dapat diterima oleh masyarakat.

Dengan dilakukannya pengungapan Corporate social responsibility maka diharapkan investor akan memperhatikan dan memberikan reaksi positif terhadap informasi-informasi yang telah diungkap karena perusahaan memperhatikan aspek sosialnya yang pada akhirnya perusahaan juga akan memperoleh manfaat berupa semakin loyalnya masyarakat terhadap perusahaan dan hal itu akan memiliki dampak pada peningkatan penjualan perusahaan, hal itu juga tentu akan memberikan keuntungan para pemegang saham sehingga nilai perusahaan juga akan semakin tinggi. Prinsip signaling mengatakan "Actions Convey Information"(Atmaja, 2008:6). Prinsip ini mengandung arti bahwa setiap tindakan yang dilakukan perusahaan mengandung sebuah informasi. Informasi inilah merupakan pemberian sinyal kepada investor tentang keputusankeputusan manajemen selanjutnya tergantung investor mempersepsikan informasi tersebut apakah bernilai positif ataukah negatif.

Hasil Penelitian menunjukkan bahwa Corporate social responsibility disclosure memiliki pengaruh terhadap nilai perusahaan artinya informasi Corporate social 
responsibility disclosure yang sampaikan oleh perusahaan tidak direspon oleh investor. Hal-hal yang mungkin dapat menjadi penyebabnya ialah Corporate social responsibility disclosure hanyalah sebuah formalitas saja yang ingin perusahaan tunjukkan kepada investor dan para stakeholders. Selain itu, belum adanya regulasi resmi dari pemerintah yang mewajibkan perusahaan untuk mengungkapkan Corporate social responsibility sehingga pengungkapan mengenai Corporate social responsibility hanyalah bersifat sukarela dan investor tidak mengapresiasi Corporate social responsibility disclosure sebagai bahan pertimbangan penilaian perusahaan dalam menginvestasikan modalnya

Hasil ini juga tidak mampu mendukung signanling theory yang menyebutkan bahwa investor akan merespon informasi-informasi yang disampaikan oleh perusahaan baik berupa informasi keuangan ataupun non keuangan sebagai bahan pertimbangan investasinya. Hasil penelitian ini selaras dengan hasil penelitian (Mutmainah, 2015; Stacia \& Juniarti, 2015; Fajriana \& Priantinah, 2016; dan Putra \& Wirakusuma, 2017;) yang menyebutkan bahwa Investor dan para stakeholders yang lain belum menangkap informasi tanggung jawab sosial perusahaan secara tepat karena sebagian besar perusahaan public hanya berfokus pada faktor keuangan dan menganggap Corporate social responsibility hanyalah bersifat formalitas perusahaan. (Mutmainah, 2015). Selain itu, Stakeholder tidak begitu memperhatikan aktivitas CSR yang dilakukan perusahaan serta pelaporan CSR pun belum sepenuhnya dihargai oleh investor karena regulasi mengenai kewajiban pelaksanaan CSR di Indonesia yang baru dikeluarkan oleh pemerintah tahun 2007 yaitu Undang-Undang No 40 Tahun 2007 Pasal 74 tentang Tanggung Jawab Sosial dan Lingkungan Perseroan Terbatas (Stacia \& Juniarti, 2015). Kemudian masih rendahnya kualitas pengungkapan yang dilakukan perusahaan serta belum sepenuhnya mengikuti standar yang dikeluarkan oleh GRI ( Fajriana \& Priantinah, 2016) Serta adanya reaksi negatif dari investor, dimana nilai perusahaan tidak akan terjamin tumbuh berkelanjutan dengan cara perusahaan memperhatikan dimensi ekonomi,

\section{$\underline{\text { Pengaruh Scoring Good Corporate Governance Terhadap Nilai Perusahaan }}$}

Scoring good corporate governance merupakan representasi yang digunakan dalam menilai seberapa baik perusahaan dalam menerapkan good corporate governance.Tujuan utama dari pengelolaan perusahaan yang baik yaitu memberikan 
perlindungan dan perlakuan yang adil kepada pemegang saham dan stakeholder lainnya melalui memaksimalkan peningkatan nilai . (Emirzon, 2006) Pengelolaan yang baik bukan hanya sekedar upaya menjaga agar perusahaan bekerja sesuai norma dan peraturan yang berlaku namun pengelolaan perusahaan yang baik itu diketahui oleh public dan para stakeholders sehigga mereka benar-benar yakin menginvestasikan modalnya terhadap perusahaan tersebut. (Emirzon, 2006).

Kualitas penerapan GCG yang dilakukan perusahaan dapat diketahui melalui self assessment perusahaan yang diungkapkan melalui laporan GCG perusahaan. Semakin mendekati angka 1 skor GCG yang diperoleh perusahaan maka semakin baik perusahaan dalam menerapkan good corporate governance. Good corporate governance dipersepsikan sebagai hal yang positif oleh investor karena fungsinya sebagai sistem pengendali dalam perusahaan dapat mencegah serta mampu mengurangi terjadinya konflik keagenan dalam perusahaan (Randy dan Juniarti, 2013).

Hasil penelitian menunjukkan bahwa Scoring good corporate governance berpengaruh negatif signifikan terhadap nilai perusahaan. Hal ini menandakan bahwa investor menilai Scoring good corporate governance yang diperoleh perusahaan sebagai sesuatu informasi yang negatif. Adapun tiga alasan yang mungkin menjadi penyebabnya, yang pertama investor tidak mengapresiasi Scoring good corporate governance sebagai dasar penilaian perusahaan dalam menginvestasikan modalnya. Kedua, Scoring good corporate governance hanya dijadikan sebuah lip service karena banyak perusahaan yang memiliki nilai GCG tinggi namun dewan direksi perusahaan masih banyak yang tersangkut kasus KPK. Ketiga, perusahaan menjadikan Scoring good corporate governance hanya sebagai formalitas untuk mematuhi regulasi yang ada mengenai good corporate governance. Hasil penelitian ini juga mampu mendukung Signaling Theory yang menyatakan bahwa investor akan bereaksi terhadap informasi yang diberikan perusahaan namun pada penelitian ini informasi yang diberikan perusahaan mengenai Scoring good corporate governance oleh investor dinilai sebagai informasi yang negatif. Hasil penelitian ini sejalan dengan penelitian yang dilakukan Mutmainnah (2015) yang menyatakan bahwa Good Corporate Governance (GCG) berpengaruh negatif secara signifikan terhadap Nilai. Ia menyebutkan bahwa Praktek GCG yang dilakukan 
perusahaan memang dilaksanakan namun hal itu masih belum diterapkan secara maksimal oleh perusahaan artinya praktek GCG yan dilakukan perusahaan hanya bersifat formalitas untuk memenuhi kewajiban perusahaan pada peraturan yang telah ditetapkan oleh pemerintah sehingga investor pun menganggap praktek GCG bukanlah bahan pertimbangan dalam menilai perusahaan.

\section{Peran kepemimpinan perempuan dalam memoderasi pengaruh corporate social}

\section{responsibility disclosure terhadap nilai perusahaan}

Hasil penelitian menunjukkan bahwa dewan direksi perempuan memiliki peranan memperkuat dalam memoderasi hubungan atau pengaruh corporate social responsibility disclosure terhadap nilai perusahaan. Dengan kehadiran perempuan dalam perusahaan, maka perusahaan dianggap telah menerapkan praktek tata kelola yang baik. Keterlibatan perempuan dalam jajaran dewan direksi dan dewan komisaris perusahaan mencerminkan tidak adanya deskriminasi dalam perusahaan, artinya perusahaan memberikan kesempatan kepada siapapun untuk menjadi bagian dari dewan perusahaan, persepsi itu yang akan meningkatkan reputasi dan nilai perusahaan terhadap investor (Kristina \& Wiratmaja, 2018). Dalam hal memipin, gaya kepemimpinan yang digunakan perempuan yaitu kepemimpinan kolaboratif, dengan tipe kepemimpinan ini akan memberikan keuntungan pada dewan direksi melalui peningkatan mendengarkan inovasi, keluhan karyawan, dukungan sosial, dan penggunaan strategi win-win solution (Sudana dan W Arlindania, 2011).

Hasil penelitian ini sejalan dengan penelitian Gordini \& Rancati, 2017; Gomez, 2018; Jubilee, et.al., 2018 yang menyebutkan bahwa keberadaan dewan perempuan pada perusahaan memiliki dampak yang positif signifikan terhadap nilai perusahaan. Dengan keberagaman yang lebih besar maka potensi penghasilan perusahaan dimasa depan akan lebih efektif (Gordini \& Rancati, 2017). Selain itu, Keberagaman gender akan memiliki potensi yang lebih besar karena tidak hanya memahami pasar tetapi juga hubungan eksternal sehingga akan lebih meningkatkan kreativitas dan inovasi perusahaan. (Jubilee, et.al., 2018). 


\section{Peran kepemimpinan perempuan dalam memoderasi pengaruh scoring good corporate governance terhadap nilai perusahaan}

Hasil penelitian menunjukkan bahwa dewan direksi perempuan memiliki peranan memperkuat dalam memoderasi pengaruh scoring good corporate governance terhadap nilai perusahaan. Kehadiran perempuan dalam direksi perusahaan sebagai solusi masalah keagenan dalam perusahaan. Kehadiran perempuan dapat menjadi alat kontrol serta meningkatkan independensi dewan dalam memantau perusahaan agar tidak menciptakan nilai bagi pemegang saham yang dapat merugikan yang lain (Carter, et.al., 2003). Selain itu, kehadiran perempuan memastikan bahwa prosedur pemantauan dan pengawasan yang diikuti tepat sehingga akan memberikan kinerja keuangan yang lebih baik (MintahAgyemang \& Schadewitz 2019).

Hasil penelitian ini sejalan dengan penelitian Gordini \& Rancati, 2017; Gomez, 2018; Jubilee, et.al., 2018; Mintah-Agyemang \& Schadewitz, 2019 yang meyatakan bahwa keberadaan dewan perempuan pada perusahaan memiliki dampak yang positif signifikan terhadap nilai perusahaan. Perbedaan gender akan menyebabkan perbedaan perilaku yang akan mengarah kepada pengambilan keputusan (Gomez, 2018). Selain itu dengan kehadiran perempuan dalam dewan akan memastikan mekanisme tata kelola yang dijalankan tepat sehingga akan menghasilkan kinerja keuangan yang baik (MintahAgyemang \& Schadewitz, 2019).

\section{KESIMPULAN}

Hasil penelitian kami dapat disimpulkan bahwa secara parsial Corporate Social Responsibility disclosure tidak memiliki pengaruh terhadap nilai perusahaan sedangkan Scoring Good Corporate Governance memiliki pengaruh negatif signifikan terhadap Nilai Perusahaan. Selain itu kepemimpinan perempuan dalam dewan direksi berperan sebagai pure moderasi yang dapat memperkuat pengaruh Corporate Social Responsibility disclosure terhadap nilai perusahaan serta memperkuat pengaruh Scoring Good Corporate Governance terhadap Nilai Perusahaan. Adanya keterlibatan perempuan dalam jajaran dewan perusahaan maupun dewan komisaris mencerminkan bahwa tidak ada dekriminasi dalam perusahaan, artinya perusahaan memberikan kesempatan kepada 
siapapun untuk menjadi bagian dari dewan perusahaan, dengan begitu akan reputasi dan nilai perusahaan investor akan mengalami peningkatan.

Keragaman dalam direksi sebagai solusi masalah keagenan antara agen dengan partisipal. Kehadiran perempuan dapat menjadi alat kontrol serta meningkatkan independensi dewan dalam memantau perusahaan agar tidak menciptakan nilai bagi pemegang saham yang dapat merugikan yang lain. Selain itu dalam hal memipin, gaya kepemimpinan yang digunakan perempuan yaitu kepemimpinan kolaboratif, dengan tipe kepemimpinan ini akan memberikan keuntungan pada dewan direksi melalui peningkatan mendengarkan inovasi, keluhan karyawan, dukungan sosial, dan penggunaan strategi winwin solution. Sikap kehati-hatian tinggi yang dimiliki perempuan dan lebih cenderung menghindari risiko (risk avoidance) serta lebih teliti jika dibandingkan dengan laki-laki yang membuat perempuan tidak terburu-buru dalam mengambil suatu keputusan. Dengan adanya wanita di dalam jajaran direksi dapat membantu dalam hal pengambilan keputusan yang lebih tepat dan memiliki risiko yang lebih rendah.

Keterbatasan penelitian ini ialah pengunaan pengukuran keterlibatan dewan direksi dan penggunaan score GCG yang masih sederhana serta objek penelitian yang masih dalam lingkup sub sektor sehingga saran bagi peneliti selanjutnya adalah menggunakan indeks Blau maupun Index Shannon dalam mengukur keterlibatan dewan direksi serta peneliti selanjutnya dapat menggunakan hasil penilaian skor GCG dari pihak eksternal perusahaan. baik score CGPI maupun Asean Score. Selain itu, mengenai dewan direksi perempuan perlu dilakukan penelitian yang lebih meluas pada sub sektor dan sektor perusahaan Indonesia.

\section{DAFTAR PUSTAKA}

Aluy, Claudia Aprilinda dkk (2017) Pengaruh Keberadaan Wanita Dalam Manajemen Puncak Dan Kepemilikan Manajerial Terhadap Kinerja Keuangan Perbankan. Jurnal EMBA, Vol.5 No.2, Hal. 821-828

Ardiyanto, Taufan \& Haryanto. (2017). Pengaruh Pengungkapan Corporate Social Responsibility Terhadap Nilai Perusahaan Dengan Kinerja Keuangan Sebagai 
Variabel Intervening.. Diponegoro Journal Of Accounting Volume 6, Nomor 4, Tahun 2017, Halaman 1-15

Atmaja., Lukas Setia. (2008). Teori dan Praktik Manajemen Keuangan. Ed.I.

Yogyakarta: ANDI.

Bawafi, Muh Hosen \& Adi Prasetyo. (2015). Pengaruh Pengungkapan Corporate Social

Responsibility Terhadap Nilai Perusahaan Dengan Profitabilitas Sebagai Variabel

Pemoderasi. Jurnal Reviu Akuntansi Dan Keuangan. Vol.5 No.1, Pp 721-730.

Carnicer-Luis, Pilar de et.al. (2008). Gender Diversity in Management: Curvilinier Relationships To Reconcile Findings. Gender In Management: An International Journal. Vol. 23 No.8, pp. 583-597.

Carter, David A. et.al. (2003). Corporate Governance, Board Diversity, and Firm Value.

The Financial Review. 38: 33-53

Ekasari, Novita \& Christine, Yenny. (2012). Pengaruh Corporate Social Responsibility

Terhadap Profitabilitas Pt. Telkom Tbk Sebagai Pemenang CSR Award 2008.

Akrual 3 (2): 196-208

Emirzon, Joni. (2006) Regulatory Driven Dalam Implementasi Prinsip-Prinsip Good

Corporate Governance Pada Perusahaan Di Indonesia. Jurnal Manajemen \& Bisnis Sriwijaya Vol. 4., No. 8

Fajriana, Ardianti. (2016). Pengaruh Corporate Social Responsibility, Keputusan Investasi, Dan Struktur Modal Terhadap Nilai Perusahaan. Jurnal Nominal / Volume V Nomor 2.

Gomez, et al. (2018). Gender Diversity In The Board, Women's Leadership And Business Performance. Gender In Management: An International Journal, Vol. 33 No.2, Pp. 104.122.

Gordini, Niccolo \& Rancati, Elisa. (2017). Gender Diversity In The Italian Boardroom And Firm Financial Performance. Management Research Review, Vol.40. 1, Pp.7594

https://www.beritasatu.com, 2018

Inastri, Mirsha Amirah \& Mimba, Putu Sri Harta. (2017). Pengaruh Penerapan Good Corporate Governance Dan Pengungkapan Corporate Social Responsibility Pada Nilai Perusahaan. E-Jurnal Akuntansi Universitas Udayana Vol.21.2:1400-1429. 
Istikhoroh, Siti \& Suhardiyah, Martha. (2016). Peran Pengungkapan Corporate Social Responsibility Dalam Meningkatkan Pengaruh Return On Equity Terhadap Nilai Perusahaan. Majalah Ekonomi, Vol.XXI, No. 2

Jubilee, Ribed Vianneca W. et.al. (2018). Would Diversity Corporate Boards Add Value? The Case Of Banking Institutions In Malaysia. Asia-Pasific Journal Of Business Administration, Vol.10 No.23, pp. 218-4323.

Khairandy, Ridwan \& Camelia Malik (2007). Good Corporate Governance: Perkembangan Pemikiran dan Implementasinya di Indonesia dalam Perspektif Hukum. Jogjakarta: Total Media Yogyakarta.

Khairani, Nadia \& Harahap, Devianti Yunita. (2017) Firms Value : From The Board Diversity And Board Compensation Perspective. Jurnal Riset Akuntansi Dan Keuangan, 5 (3), 1551-1564.

Kristina, I Gusti Agung Rai \& Wiratmaja, I Dewa Nyoman (2018). Pengaruh Board Diversity Dan Intellectual Capital Pada Nilai Perusahaan. E-Jurnal Akuntansi Universitas Udayana, Vol.22.3, 2313-2338.

Li, Haishan \& Peng Chen (2018) Board Gender Diversity and Firm Performance: The Moderating Role Of Firm Size. Business Ethic A Eur Rev.27:297-308

Limanto, Anthomi Wibisono dan Juniarti. (2014). Pengaruh Penerapan Good Corporate Governance Terhadap Nilai Perusahaan Yang Terdaftar Di Bursa Efek Indonesia 2007-2011. Business Accounting Review, Vol.2, No.1.

Mintah-Agyemang, Peter \&Schadewitz, Hannu. (2019). Gender Diversity and Firm Value: Evidence from UK Financial Instutions. International Journal Of Accounting \& Information Management. Vol.27 No.1, pp. 2-26.

Mirfazli, Edwin. (2008). Evaluate Corporate Social Responsibility Disclosure at Annual Report Companies In Multifarious Group Of Industry Members Of Jakarta Stock Exchange (JSX) Indonesia. Social Responsibility Journal. Vol.4 No.3, pp 388-406.

Mutmainah. (2015) Analisis Good Corporate Governance Terhadap Nilai Perusahan. EKSIS. Volume X No. 2

Nahda, Katiya \& Harjito, D. Agus. (2011). Pengaruh Corporate Social Responsibility Terhadap Nilai Perusahaan Dengan Corporate Governance Sebagai Variabel Moderasi. Jurnal Siasat Bisnis, Vol. 15 No. 1, Hal: 1-12. 
Nofiani, Fifi \& Nurmayanti, Poppy. (2010). Pengaruh Penerapan Corporate Governance Terhadap Kinerja Keuangan Perusahaan. Pekbis Jurnal, Vol.2, No.1.

Pechersky, Alexander. 2016. Diversity in Board Of Directors: Review Of Diversity As a Factor to Enhance Board Performance. Studia Commercialia Bratislavensia. Volume 9; Number 33, pp. 88-101.

Putra, Aa Gde Trisna Dwija \& Wirakusuma, Made Gede. (2017). Pengaruh Corporate Social Responsibility Disclosure Terhadap Nilai Perusahaan Dengan Kepemilikan Asing Sebagai Variabel Pemoderasi. E-Jurnal Akuntansi Universitas Udayana, Vol.19.3: 1719-1746.

Randy, Vincentius \& Juniarti. (2013). Pengaruh Penerapan Good Corporate Governance Terhadap Nilai Perusahaan Yang Terdaftar Di BEI 2007-2011. Business Accounting Review, Vol. 1, No.2.

Ratih, Suklimah \& Setyarini, Yulia. (2014). Pengaruh Good Corporate Governance (Gcg)

Dan Corporate Social Responsibility (Csr) Terhadap Nilai Perusahaan Dengan Kinerja Keuangan Sebagai Variable Intervening Pada Perusahaan Pertambangan Yang Go Public Di BEI. Akrual 5 (2) : 115-132.

Retno, Reny Dyah \& Priantinah, M. Denies. (2012). Pengaruh Good Corporate Governance Dan Pengungkapan Corporate Social Responsibility Terhadap Nilai Perusahaan (Studi Empiris Pada Perusahaan Yang Terdaftar Di Bursa Efek Indonesia Periode 2007-2010). Jurnal Nominal, Volume I Nomor I.

Rosiana, Gusti Ayu Made Ervina dkk. (2013). Pengaruh Pengungkapan CSR Terhadap

Nilai Perusahaan Dengan Profitabilitas Sebagai Variabel Pemoderasi. E-Jurnal Akuntansi Universitas Udayana $5.3: 723-738$.

Said, Roshima et. al. (2009). The Relationship Between Corporate Social Responsibility Disclosure and Corporate Governance Characteristics In Malaysian Public Listed Companies. Social Responsibility Journal. Vol.5 No.2, pp.212-226.

Salman, Putriana dkk. (2014). Faktor-Faktor Yang Mempengaruhi Pengungkapan Tata Kelola Perusahaan dan Dampaknya Terhadap Kinerja Perusahaan. El-Muhasaba. Vol.5, No.1

Setyowati,Valeria Kunthi Dkk. (2014). Pengaruh Pengungkapan Good Corporate Governance Dan Corporate Social Responsibility Terhadap Nilai Perusahaan (Pada 
Indeks Bisnis-27 Yang Terdaftar Di BEI Periode 2010-2012). Jurnal Administrasi Bisnis (JAB), Vol.15 No.1

Stacia, Evelyn \& Juniarti. (2015). Pengaruh Pengungkapan Corporate Social Responsibility Terhadap Nilai Perusahaan Di Sektor Pertambangan. Business Accounting Review, Vol.3, No.2:(81-90)

Sudana, I Made \& W Arlindania, Putu Ayu. (2011). Corporate Governance Dan Pengungkapan Corporate Social Responsibility Pada Perusahaan Go-Public Di Bursa Efek Indonesia. Jurnal Manajemen Teori dan Terapan, Tahun 4, No 1

Sukamulja, Sukmawati. (2004). Good Corporate Governance Di Sektor Keuangan: Dampak GCG Terhadap Kinerja Perusahaan (Kasus di Bursa Efek Jakarta). BENEFIT. Vol. 8, No. 1 